\title{
Optimal Complementary Auctions*
}

by

Martin Cripps and Norman Ireland

Department of Economics

University of Warwick

Coventry CV4 7AL

UK

Revised version: April 15, 2002

\begin{abstract}
Consider the situation where two products are sold by the same seller, but to disjoint sets of potential buyers. Also that externalities may arise from each market outcome to the other. This paper examines the nature of the seller's optimal mechanism, and, for example in the case of positive externalities, it is shown that the allocation decision in either market depends on the highest types in both markets. The optimal mechanism can be implemented by an indirect mechanism that essentially charges winning bidders for the value of their externalities. The analysis is applied to the sale of public sector franchises including exploration and development rights for oil and gas tracts.
\end{abstract}

* We are grateful to the Editor and referees of this Journal, and to seminar participants at the London Business School, Lei Zhang and Marcus Miller for comments on an earlier version of this paper. Financial support from the ESRC under award number R000222013 is gratefully acknowledged. 



\section{Introduction}

This paper considers the sale of two products, commercial opportunities or franchises, where consumption or operation of one yields externalities for the other. Our major focus of interest is where the externalities are positive, although we also investigate the effects of negative externalities. The analysis will concentrate on the sale of franchises and North Sea oil and gas rights as being of particular importance, although a more general "product" interpretation is possible. Positive externalities between franchises exist when the operator of one franchise benefits from the operation of the other, and, in particular, shares in the success of the other. An example that has special relevance for current policy in the UK would be the sale of franchises of complementary parts of a railway system. The demand for one part of the system will be increased, if the other is run efficiently, due to the number of passengers who wish to take journeys that encompass both parts of the system. Our interest here concerns the situation where externalities can be evaluated as soon as the identities of the winning bidders are revealed. Other examples of such externalities abound. For instance, franchises for different kinds of store on a new shopping development would have a number of supermarket chains bidding for one franchise, while a number of "do-it-yourself" chains would bid for the franchise of the neighbouring site. Here the better the winning chain (in relation to the specific characteristics of the shopping centre), the more customers will be attracted, and the more another franchisee will benefit. Again a positive externality exists. These benefits relate to complementary demand. They extend to spillovers in advertising or promotion.

Another source of externalities may relate to production. For example, the costs of development of franchises may be shared, and may be better shared with more appropriate partners. An example here is the exploration and development rights of mineral deposits, and an issue of public concern in the UK is the revenue that can be 
generated from North Sea oil and gas deposits. The issue here is that a number of elements of costs both in exploration (supply to the exploration rigs, the design pattern of exploratory wells, and geological surveys) can be reduced by appropriate cooperation. Also both supply and extraction costs can be reduced by cooperative development plans. At the same time it remains a key element of UK government policy to sustain the interest of all current operators in the North Sea. Thus allocations must be made so that for the most part all the operators share in the development of new fields. A simple auction of each tract is thus inappropriate. Similarly simple auctions of each rail franchise is inappropriate from the point of view of competition policy. We need to incorporate the externalities into a simultaneous auction mechanism.

Simultaneous mechanisms have recently become well-known due to the activities of the Federal Communications Commission (FCC) in the USA and derivative activity. The FCC adopted open simultaneous auctions for the sale of radio spectrum in a series of over 20 auctions in the late 1990's. Although there were eligibility criteria and preregistrations built into these auctions, there was no way in which the price of one franchise or license could affect the required bidding for another apart from the general competition across licenses. A description of the early auctions is given in Cramton (1997). The FCC model has been adopted by other governments. The UK government held a simultaneous English auction in March-April 2000 to allocate 5 licenses for the next generation of mobile telephone communications (UMTS auction) which attracted 13 bidders and raised $£ 22.5$ billion in license fees. In this auction one license was restricted for new entrants so that firms already in the market were excluded, while new entrants could bid for any license. In the early plans for the auction mechanism (but dropped from the final plan) was the notion of ratcheted reserve prices for the unrestricted licenses, with the ratchet depending on the current bid for the restricted license. The idea was to ensure that the prices for the unrestricted licenses fully reflected the demands for the 
restricted license. One interpretation would be that the prices that the incumbents paid would have to properly reflect the entrants' willingness to pay. From a technical standpoint it raised the issue of a simultaneous auction with cross effects on reserve prices. Our analysis of externalities will focus on this kind of mechanism.

More generally, the question arises as to whether the kind of externalities we have discussed have significant implications for the raising of revenue from the sale of franchises, rights or licenses. This question will be addressed here. We will argue that the seller's revenue maximizing behaviour will involve a joint auction mechanism, rather than independent mechanisms. A very simple example can help understanding and we will describe this first.

Suppose that there is but one risk-neutral bidder for each of two franchises. The two franchises are termed $\mathrm{V}$ and $\mathrm{W}$. The bidder for $\mathrm{V}$ will benefit from running the franchise by an amount $\mathrm{v}+\mathrm{w}$. Here $\mathrm{v}$ is the bidder's type, while $\mathrm{w}$ is the type operating the $\mathrm{W}$ franchise. If the $\mathrm{W}$ franchise is not operated then $\mathrm{w}=0$. Similarly the bidder for $\mathrm{W}$ will benefit by $\mathrm{w}+\mathrm{v}$. Suppose that the bidder types are private information, but that it is common knowledge that the types are independently drawn from the set $\{0, \alpha, 1\}$ with equal probabilities of $(1 / 3,1 / 3,1 / 3)$. The common seller (the government) can set a takeit-or-leave-it price for each franchise to the single potential buyer of that franchise. If a franchise is not purchased then it is not operated. The government thus has to weigh the possibility of setting too low a price against exceeding the bidder's willingness to pay. ${ }^{1} \mathrm{It}$ is assumed that the mechanism announced by the government (the price) is credible: for example, if the government "cheated" and put an unsold franchise up for sale at a later date, and at a lower price, this would destroy the credibility of any future announcements.

\footnotetext{
${ }^{1}$ This is the standard trade-off in optimal mechanism design: see Myerson (1981), Riley and Samuelson (1981) and particularly Bulow and Roberts (1989).
} 
This lost credibility would be sufficient deterrent to prevent cheating. With only one bidder for each franchise the form of the auction is largely irrelevant, with the reserve price the dominant instrument.

Consider first the outcomes from the sales if the two franchises are sold independently and simultaneously. An efficient outcome is achieved by the government setting a price of (slightly less than) $0+(1+\alpha) / 3$ for each franchise. Then allocations are made even if the bidder has a zero type, since even such a bidder would not lose in expectation because, for a V-bidder, $E(w)=(1+\alpha) / 3$. An allocation even to a 0 -type is necessary for efficiency since the franchise may still have positive worth due to the externality from the other franchisee. However, such low prices yield only an amount of expected government revenue $\mathrm{R}^{0}=(1+\alpha) / 3$ for each franchise. If the price was set at $\alpha+(1+\alpha) / 3$, only types $\alpha$ or 1 will purchase. Expected revenue per franchise is then $\mathrm{R}^{\alpha}=[\alpha+(1+\alpha) / 3](2 / 3)$ since the probability of a sale is $2 / 3$. Finally at prices $1+1 / 3$ only type 1 bidders will buy. Then the expected revenue per franchise is $\mathrm{R}^{1}=[1+1 / 3](1 / 3)$ since the probability of a sale is $1 / 3$, and $\mathrm{E}(\mathrm{w})$ for a $\mathrm{V}$-bidder is $1 / 3$. It is easily seen that the seller's revenue is maximized in independent sales by the following mechanism:

if $\alpha<1 / 4$, set prices at $4 / 3$ and have expected revenue per franchise of $4 / 9$.

if $\alpha \geq 1 / 4$, set prices at $\alpha+(1+\alpha) / 3$ and have expected revenue per franchise of $2 / 9+8 \alpha / 9$.

Aggregate expected revenue is just double the per-franchise expected revenue. A property of this mechanism is that if $\alpha<1 / 4$ there is a $2 / 3$ chance that a particular franchise will not be allocated, while if $\alpha \geq 1 / 4$ there is a $1 / 3$ chance of such nonallocation. 
The central thrust of our argument will be that the above mechanism is not optimal for the sale of the two franchises since it does not make use of their complementary nature. We consider below a simple joint mechanism that does utilize this property.

The values of $\mathrm{r}^{*}$ and $\mathrm{s}^{*}$ are announced by the seller before bids are made. Let each bidder state a pair of numbers ( $r, s)$. If the bidder for $V$ sets $r \geq r^{*}$ and the other franchise (franchise W) is not allocated, then franchise V is allocated to the bidder for a price of $\mathrm{r}^{*}$. If the bidder for $\mathrm{V}$ sets $\mathrm{s} \geq \mathrm{s}^{*}$ and franchise $\mathrm{W}$ is allocated, then franchise $\mathrm{V}$ is allocated at price $\mathrm{s}^{*}$. Otherwise (if $\mathrm{r}<\mathrm{r}^{*}$ when $\mathrm{W}$ is not allocated or $\mathrm{s}<\mathrm{s}^{*}$ when $\mathrm{W}$ is allocated) franchise $\mathrm{V}$ is not allocated. The allocation of $\mathrm{W}$ is determined by a symmetric rule. Furthermore, if both $\mathrm{V}$ and $\mathrm{W}$ bidders choose $\mathrm{r}<\mathrm{r}$ then both franchises will be allocated if both bidders choose $\mathrm{s} \geq \mathrm{s}^{*}$; otherwise neither franchise will be allocated.

The values of $\mathrm{r}^{*}$ and $\mathrm{s}^{*}$, and the contingencies under which they are relevant, constitute the mechanism in the joint selling procedure. The issue is whether the contingent nature of the bidding permits the seller to encourage bids from both when both types are middle values (types $\alpha$ rather than zero or one) while maintaining high reserve prices when a high type is paired with a zero type. Obviously in equilibrium the single bidder for each franchise states either $r=r^{*}$ or $r<r^{*}$, the latter equivalent to "no bid" in the contingency that the other franchise is not allocated. Similarly $\mathrm{s}=\mathrm{s}^{*}$ or $\mathrm{s}<\mathrm{s}^{*}$. Thus consider the design

$\mathrm{r}^{*}=1 ; \mathrm{s}^{*}=\alpha+(1+\alpha) / 2$ 
Only a type 1 will accept the price $\mathrm{r}^{*}$ since there are no externalities in this case (the "r" price is only relevant if the other franchise is not allocated). A type $\alpha$ will just accept ${ }^{2}$, and a type 1 will accept with positive profit, the price $\mathrm{s}^{*}$, since this is equal to a type $\alpha$ 's expected value if it is the case that a type $\alpha$ or 1 is allocated the other franchise. The revenue from the joint auction is $r^{*}$ if one type is 1 and the other type is 0 . This is because only one franchise is allocated, and this occurrence has probability $2 / 9$. The revenue is $2 \mathrm{~s} *$ if both types are $\alpha$ or 1 . The probability of this is $4 / 9$. Thus the expected revenue from the joint mechanism is

$R \mathrm{j}=2 / 3+4 \alpha / 3$.

Now $\mathrm{R}^{\mathrm{j}}>2 \mathrm{R}^{1}$ if $\alpha>1 / 6$, and $\mathrm{R}^{\mathrm{j}}>2 \mathrm{R}^{\alpha}$ if $\alpha<1 / 2$. Thus for $1 / 6<\alpha<1 / 2$, the joint mechanism above permits strictly higher expected revenue for the government than the independent mechanism. ${ }^{3}$ The difference in price between $\mathrm{r}^{*}$ and $\mathrm{s}^{*}$ can be positive ( $\mathrm{r}^{*}>\mathrm{s} *$ if $\left.\alpha<1 / 3\right)$ ) or negative (if $\alpha>1 / 3$ ). In all cases, the mechanism offers inducements to cooperate in joint participation of the franchises since any premium is less than the expected value of the externality. If the mechanism encourages more participation in $\mathrm{V}$ if $\mathrm{W}$ is proceeding, and vice-versa, then more revenue can be extracted by the seller.

It might be thought that holding the sales sequentially rather than simultaneously goes some way towards capturing the advantage of the joint auction. If the sale of $\mathrm{V}$ took place prior to that of $\mathrm{W}$ and the outcome of the sale of $\mathrm{V}$ became common knowledge, then the sale of $\mathrm{W}$ would reflect full information while the sale of $\mathrm{V}$ takes place in the expectation of the sale of W. Thus we have a "one-sided" contingent bidding. To demonstrate that

\footnotetext{
${ }^{2}$ The values $r^{*}, \mathrm{~s}^{*}$ can be interpreted as epsilon below $1, \alpha+(1+\alpha) / 2$ in order to break the "tie" in buyers' preferences.

${ }^{3}$ For $\alpha$ outside this range, the limitation to three discrete types means that there is no strictly positive gain (but no loss) from using the joint mechanism. This would be analogous to the breakdown of the regularity condition used in section 2 .
} 
this is indeed a halfway house between independent and joint mechanisms, we take the above model and a value of $\alpha=0.4$. This value yields an advantage of the joint auction $\left(R^{j}=1.2\right)$ over independent auctions $\left(2 R^{\alpha}=104 / 90\right)$. In the sequential auction, the contingencies that can arise at the second (W) stage are that $\mathrm{v}$ is in $\{0,0.4,1\}$. If it is zero, and the seller sets a reserve price of $r_{w}=1$, expected revenue is $R_{w}(v=0)=10 / 30$ and the expected $\mathrm{w}$ is $\operatorname{Ew}(\mathrm{v}=0)=10 / 30$. This is the seller's best action that can be selected in this contingency. If $\mathrm{v}=0.4$, then the best reserve price is 0.8 , leading to $\mathrm{R}_{\mathrm{w}}(\mathrm{v}=0.4)=$ $16 / 30$ and $\mathrm{Ew}(\mathrm{v}=0.4)=14 / 30$. If $\mathrm{v}=1$, then the best reserve price is 1 , and $\mathrm{R}_{\mathrm{w}}(\mathrm{v}=1)=1$ and $\operatorname{Ew}(v=1)=14 / 30$. Now consider the first auction. If the seller wishes all types to be willing to meet the reserve price then the reserve is set at $0+$ $[\operatorname{Ew}(v=0)+\operatorname{Ew}(v=0.4)+\operatorname{Ew}(v=1)] / 3=38 / 90$. If the reserve is set to attract the types 0.4 and above, then it is $0.4+[\operatorname{Ew}(\mathrm{v}=0.4)+\operatorname{Ew}(\mathrm{v}=1)] / 2=78 / 90$, since a type 0.4 would be able to rule out the $\mathrm{v}=0$ contingency. To attract only types 1 , it is set at $1+[\operatorname{Ew}(v=1)]=$ $132 / 90$. The best reserve price is $78 / 90$, since then the expected revenue from the $\mathrm{V}$ auction is $52 / 90$, because there is a $2 / 3$ chance of a sale, and the expected revenue from the $\mathrm{W}$ auction is $\left[\mathrm{R}_{\mathrm{W}}(\mathrm{v}=0)+\mathrm{R}_{\mathrm{W}}(\mathrm{v}=0.4)+\mathrm{R}_{\mathrm{W}}(\mathrm{v}=1)\right] / 3=(1 / 3+16 / 30+1) / 3=56 / 90$. The total expected revenue is then $108 / 90=1.2$. This is the best that can be achieved by the seller in the sequential auction, and is between the value achieved in the simple auctions and that achieved in the joint auction. Henceforth, we will not be concerned with the topic of sequential designs in this paper. The informational issues they present are tangential to our arguments here. ${ }^{4}$

The literature on selling mechanisms is huge, and well-known surveys include McAfee and McMillan (1987) and Klemperer (1999). Most contributions, beginning with the seminal paper by Vickrey (1961) have concentrated on the selling of a single product.

\footnotetext{
${ }^{4}$ We conjecture that even if the principal was allowed to choose a sequential mechanism, she would always prefer to use a simultaneous mechanism in this model.
} 
The optimal mechanism for the single product sale is discussed in Myerson (1981), Riley and Samuelson (1981) and Bulow and Roberts (1989). The sale of multiple units to buyers who have decreasing-slope demand functions for the product is analysed by Maskin and Riley (1989). In that paper, bidders have independent demand functions and the seller sets a payment schedule, requiring minimum prices contingent on the quantity chosen by the bidder. The bidders choose a price/quantity point on this schedule, and any excess demand is removed by a rationing rule. Our analysis focuses on a rather different problem, where demands are not independent due to the externalities. Nevertheless, we will also find an outcome that takes the form of a schedule, to which the bidder must supply information.

Another focus in the literature has been on package or combinatorial bidding where a simultaneous auction permits bidding for perhaps single or combinations of objects by a bidder The issue in this class of models is to endogenise the possible economies of scope that could ensue from particular types of outcome: for instance it might be optimal to permit a bidder to bid for both franchises if this yields economies which increase bids. Such an approach is about to enter the spectrum auction experience with the US Spectrum Auction No. 31 (see FCC (2000)). Our emphasis here is directly opposite: we wish to consider disjoint bidder sets, so that packages are disallowed or irrelevant, but that there exist significant cross effects between the individual allocations.

Other related strands of the literature include auctions where bidders are affected by externalities in the allocation even when they do not win (see e.g. Jehiel, Moldovanu and Stacchetti (1999)). Then the threat of losing adds an extra instrument to the auction design. Finally, the winning bidder's valuation of her win from an auction may depend on ex post contingencies as in Hansen (1985). Then if her type affects those contingencies then bidding over their future values (for example by stock options) may be a better 
design for the seller. These papers relate to selling a single object rather than to the sale of objects to disjoint bidder sets.

In the next section we develop a model which incorporates a continuum of types and any number of bidders for each franchise, and the optimal mechanism is constructed. Here, the approach uses the Revelation Principle (Myerson, 1981), so that the search for the optimal mechanism can be restricted to feasible direct mechanisms. For simplicity, we restrict attention to cases where certain "regularity" conditions (Myerson, 1981) hold. In section 3, a simple "indirect" way of implementing the optimal mechanism is described. Conclusions for policy and a number of applications are considered in the final section.

\section{Optimal Direct Mechanism}

In this section we use the Revelation Principle (Myerson, 1981) to determine the optimal allocation when communication between seller and buyers is in terms of the buyers' actual types: a direct mechanism. Thus the seller can be pictured as asking the potential buyers for their types and then the buyers respond. Incentives are constructed so that the buyers do best by revealing their true types to the seller, so that the mechanism is feasible. Our model will consider two franchises (again denoted V and W), and we will assume that there are $\mathrm{n}$ and $\mathrm{m}$ bidders respectively for each franchise. For $\mathrm{V}$, each bidder's type $\mathrm{v}_{\mathrm{i}}$ is assumed to be an independent random observation on a distribution with density $\mathrm{f}(\mathrm{v})$ and distribution function $\mathrm{F}(\mathrm{v})$ with a support $[0,1]$, and for $\mathrm{W}$ each

bidder's type $\mathrm{w}_{\mathrm{j}}$ is an independent observation on a distribution with density $\mathrm{g}(\mathrm{w})$ and distribution function $\mathrm{G}(\mathrm{w})$ with support $[0,1]$. Some regularity conditions will be imposed on $\mathrm{F}(\mathrm{v})$ and $\mathrm{G}(\mathrm{w})$ later. If a bidder $\mathrm{i}$ for $\mathrm{V}$ of type $\mathrm{v}_{\mathrm{i}}$ is allocated $\mathrm{V}$, and a bidder $\mathrm{j}$ of type $\mathrm{w}_{\mathrm{j}}$ is allocated $\mathrm{W}$, then the values to $\mathrm{i}$ and $\mathrm{j}$ are 
$\mathrm{U}_{\mathrm{i}}=\mathrm{v}_{\mathrm{i}}+\delta_{\mathrm{v}}\left(\mathrm{v}_{\mathrm{i}}, \mathrm{w}_{\mathrm{j}}\right)-\mathrm{T}_{\mathrm{i}}$

$\mathrm{U}_{\mathrm{j}}=\mathrm{w}_{\mathrm{i}}+\delta_{\mathrm{w}}\left(\mathrm{w}_{\mathrm{j}}, \mathrm{v}_{\mathrm{i}}\right)-\mathrm{T}_{\mathrm{j}}$

where $\mathrm{T}_{\mathrm{i}}, \mathrm{T}_{\mathrm{j}}$ are the transfers to the seller, and $\delta_{\mathrm{v}}\left(\mathrm{v}_{\mathrm{i}}, \mathrm{w}_{\mathrm{j}}\right)$ is the externality function affecting the winner of the $\mathrm{V}$ auction. Although a general form of this function will be maintained in the analysis, a number of regularity and feasibility conditions will need to be satisfied for the suggested solutions to be valid. These conditions are sufficient rather than necessary, and awkward to interpret. A simpler analysis is obtained if the externality is independent of the bidder's own type. This will be a feature of our examples.

In the direct mechanism, a bidder states her type. Consider the $\mathrm{i}^{\text {th }}$ bidder for $\mathrm{V}$ (the case of a bidder for $\mathrm{W}$ is symmetric). She is of type $\mathrm{v}_{\mathrm{i}}$ but may claim to be of type $\mathrm{x}_{\mathrm{i}}$. (Similarly a bidder for $\mathrm{W}$ of type $\mathrm{w}_{\mathrm{j}}$ may claim to be of type $\mathrm{y}_{\mathrm{j}}$.) For the bidder to tell the truth, truth-telling must be incentive compatible.

Given the claims $x_{i}, y_{j}$ of $i$ and $j$, and claims $x_{-i}$ and $y_{-j}$ of other bidders, where $\mathrm{x}=\left\{\mathrm{x}_{\mathrm{i}}, \mathrm{x}_{-\mathrm{i}}\right\}$, etc., the process begins by the seller announcing an allocation rule:

$\mathrm{q}_{\mathrm{i}}(\mathrm{x}, \mathrm{y})$ is the probability that $\mathrm{i}$ will be allocated $\mathrm{V}$ and $h_{j}(y, x)$ is the probability that $j$ will be allocated $W$

We look for a Nash equilibrium in truth-telling, and so as far as an individual bidder $\mathrm{i}$ is concerned, she conjectures $\mathrm{x}_{-\mathrm{i}}=\mathrm{v}_{-\mathrm{i}}$, and $\mathrm{y}=\mathrm{w}$. If $\mathrm{i}$ claims $\mathrm{x}_{\mathrm{i}}$, other bidders have types $\mathrm{v}_{-\mathrm{i}}$, $\mathrm{w}$, and other bidders all tell the truth, then from i's perspective: 
$\mathrm{q}_{\mathrm{i}}\left(\mathrm{x}_{\mathrm{i}}, \mathrm{v}_{-\mathrm{i}}, \mathrm{W}\right)$ is the probability that $\mathrm{i}$ will be allocated $\mathrm{V}$ and $\mathrm{h}_{\mathrm{j}}\left(\mathrm{W}, \mathrm{x}_{\mathrm{i}}, \mathrm{V}_{-\mathrm{i}}\right)$ is the probability that $\mathrm{j}$ will be allocated $\mathrm{W}$.

The expected payment by bidder $\mathrm{i}$ is summarized as $\mathrm{R}_{\mathrm{i}}\left(\mathrm{x}_{\mathrm{i}}\right)=\mathrm{E}_{\mathrm{V}_{-} \mathrm{i}},{ }_{\mathrm{W}} \mathrm{R}_{\mathrm{i}}\left(\mathrm{x}, \mathrm{v}_{-\mathrm{i}}, \mathrm{w}\right)$, where $\mathrm{E}_{\mathrm{V}_{-} \mathrm{i}, \mathrm{W}}$ denotes the expectation over all elements of $\mathrm{v}$ (except for $\mathrm{v}_{\mathrm{i}}$ ) and all elements of w. All bidders are risk-neutral, and there are no preparation costs. Thus the expected utility of a bidder of type $v_{i}$, claiming to be of type $x_{i}$, is given by

$\mathrm{U}_{\mathrm{i}}\left(\mathrm{x}_{\mathrm{i}}, \mathrm{v}_{\mathrm{i}}\right)=\mathrm{E}_{\mathrm{v}_{-} \mathrm{i}, \mathrm{w}}\left[\mathrm{q}_{\mathrm{i}}\left(\mathrm{x}_{\mathrm{i}}, \mathrm{v}_{-\mathrm{i}}, \mathrm{w}\right)\left(\mathrm{v}_{\mathrm{i}}+\Sigma_{\mathrm{j}}\left\{\mathrm{h}_{\mathrm{j}}\left(\mathrm{w}, \mathrm{x}_{\mathrm{i}}, \mathrm{v}_{-\mathrm{i}}\right) \delta_{\mathrm{v}}\left(\mathrm{v}_{\mathrm{i}}, \mathrm{w}_{\mathrm{j}}\right)\right\}\right]-\mathrm{R}_{\mathrm{i}}\left(\mathrm{x}_{\mathrm{i}}\right)\right.$.

For truth-telling to be incentive compatible, (3) must be maximized with respect to $\mathrm{x}_{\mathrm{i}}$ at $\mathrm{x}_{\mathrm{i}}=\mathrm{v}_{\mathrm{i}}$. This then implies by the Envelope Theorem that

$\mathrm{dU}_{\mathrm{i}}\left(\mathrm{v}_{\mathrm{i}}, \mathrm{v}_{\mathrm{i}}\right) / \mathrm{dv}_{\mathrm{i}}=\mathrm{E}_{\mathrm{v}_{-\mathrm{i}}, \mathrm{w}}\left[\mathrm{Q}_{\mathrm{i}}\left(\mathrm{v}_{\mathrm{i}}, \mathrm{v}_{-\mathrm{i}}, \mathrm{w}\right)\right]$

where $\mathrm{Q}_{\mathrm{i}}\left(\mathrm{v}_{\mathrm{i}}, \mathrm{v}_{-\mathrm{i}}, \mathrm{w}\right)=\mathrm{q}_{\mathrm{i}}\left(\mathrm{v}_{\mathrm{i}}, \mathrm{v}_{-\mathrm{i}}, \mathrm{w}\right)\left(1+\Sigma_{\mathrm{j}}\left\{\mathrm{h}_{\mathrm{j}}\left(\mathrm{w}, \mathrm{v}_{\mathrm{i}}, \mathrm{v}_{-\mathrm{i}}\right) \delta_{\mathrm{v}}{ }^{\prime}\left(\mathrm{v}_{\mathrm{i}}, \mathrm{w}_{\mathrm{j}}\right)\right\}\right.$

where $\delta_{\mathrm{v}}{ }^{\prime}\left(\mathrm{v}_{\mathrm{i}}, \mathrm{w}_{\mathrm{j}}\right)$ is the derivative of bidder i's externality function with respect to i's own type $v_{i}$. By integration of (4) we have that

$\mathrm{U}_{\mathrm{i}}\left(\mathrm{v}_{\mathrm{i}}, \mathrm{v}_{\mathrm{i}}\right)=\mathrm{U}_{\mathrm{i}}(0,0)+\mathrm{E}_{\mathrm{v}_{-} \mathrm{i}, \mathrm{w}} \quad \int_{0}^{\mathrm{v}_{\mathrm{i}}^{\mathrm{i}}} \mathrm{Q}_{\mathrm{i}}\left(\mathrm{z}, \mathrm{v}_{-\mathrm{i}}, \mathrm{w}\right) \mathrm{dz}$

Providing allocation probabilities are increasing in $\mathrm{v}_{\mathrm{i}},(4)$ is sufficient to ensure truthtelling. ${ }^{5}$ Bidder i's expected transfer to the seller is obtained from (3) and (5) as

\footnotetext{
${ }^{5}$ See for example Maskin and Riley (1989).
} 
$\mathrm{R}_{\mathrm{i}}\left(\mathrm{v}_{\mathrm{i}}\right)=\mathrm{E}_{\mathrm{v}_{-\mathrm{i}}, \mathrm{w}}\left[\mathrm{q}_{\mathrm{i}}\left(\mathrm{v}_{\mathrm{i}}, \mathrm{v}_{-\mathrm{i}}, \mathrm{w}\right)\left(\mathrm{v}_{\mathrm{i}}+\Sigma_{\mathrm{j}}\left\{\mathrm{h}_{\mathrm{j}}\left(\mathrm{w}, \mathrm{v}_{\mathrm{i}}, \mathrm{v}_{-\mathrm{i}}\right) \delta_{\mathrm{v}}\left(\mathrm{v}_{\mathrm{i}}, \mathrm{w}_{\mathrm{j}}\right)\right\}\right]-\mathrm{U}_{\mathrm{i}}\left(\mathrm{v}_{\mathrm{i}}, \mathrm{v}_{\mathrm{i}}\right)\right.$

From the seller's viewpoint, $\mathrm{v}_{\mathrm{i}}$ is also random. The seller's expected revenue from $\mathrm{i}$ is thus

$\mathrm{E}_{\mathrm{v}_{\mathrm{i}}} \mathrm{R}\left(\mathrm{v}_{\mathrm{i}}\right)=\mathrm{E}_{\mathrm{v}, \mathrm{w}}\left[\mathrm{q}_{\mathrm{i}}\left(\mathrm{v}_{\mathrm{i}}, \mathrm{v}_{-\mathrm{i}}, \mathrm{w}\right)\left(\mathrm{v}_{\mathrm{i}}+\Sigma_{\mathrm{j}}\left\{\mathrm{h}_{\mathrm{j}}\left(\mathrm{w}, \mathrm{v}_{\mathrm{i}}, \mathrm{v}_{-\mathrm{i}}\right) \delta_{\mathrm{v}}\left(\mathrm{v}_{\mathrm{i}}, \mathrm{w}_{\mathrm{j}}\right)\right\}\right]-\mathrm{E}_{\mathrm{v}_{\mathrm{i}}} \mathrm{U}_{\mathrm{i}}\left(\mathrm{v}_{\mathrm{i}}, \mathrm{v}_{\mathrm{i}}\right)\right.$,

where $\mathrm{E}_{\mathrm{v}, \mathrm{w}}$ denotes an expectation over $\mathrm{v}$ and $\mathrm{w}$ and $\mathrm{E}_{\mathrm{vi}}$ denotes an expectation taken over $\mathrm{v}_{\mathrm{i}}$. Integration by parts allows the last term to be rewritten as

$$
\begin{aligned}
& E_{v_{i}} U_{i}\left(v_{i}, v_{i}\right)-U_{i}(0,0)=E_{v_{-i}, w}\left[\int_{0}^{1} \int_{0}^{v_{i}} Q_{i}\left(z, v_{-i}, w\right) d z f\left(v_{i}\right) d v_{i}\right] \\
& =E_{v_{-i}, w}\left[\int_{0}^{1} Q_{i}\left(z, v_{-i}, w\right) d z-\int_{0}^{1} Q_{i}\left(v_{i}, v_{-i}, w\right) F\left(v_{i}\right) d v_{i}\right] \\
& =E_{v_{-i}, w}\left[\int_{0}^{1} Q_{i}\left(v_{i}, v_{-i}, w\right)\left(1-F\left(v_{i}\right)\right) d v_{i}\right] \\
& =E_{v, w}\left[Q_{i}\left(v_{i}, v_{-i}, w\right)\left(1-F\left(v_{i}\right)\right) / f\left(v_{i}\right)\right]
\end{aligned}
$$

Thus, denoting the hazard rate in the $\mathrm{V}$ auction, $\mathrm{f}() /.(1-\mathrm{F}()$.$) , as \rho_{\mathrm{v}}($.$) , the expected$ revenue from bidder $i$ is

$$
\begin{aligned}
& \mathrm{E}_{\mathrm{vi}} \mathrm{R}\left(\mathrm{v}_{\mathrm{i}}\right)=\mathrm{E}_{\mathrm{v}, \mathrm{w}}\left[\mathrm { q } _ { \mathrm { i } } ( \mathrm { v } _ { \mathrm { i } } , \mathrm { v } _ { - \mathrm { i } } , \mathrm { w } ) \left(\mathrm{v}_{\mathrm{i}}-\left(\rho_{\mathrm{v}}\left(\mathrm{v}_{\mathrm{i}}\right)\right)^{-1}+\Sigma_{\mathrm{j}}\left\{\mathrm{h}_{\mathrm{j}}\left(\mathrm{w}, \mathrm{v}_{\mathrm{i}}, \mathrm{v}_{-\mathrm{i}}\right) \delta_{\mathrm{v}}\left(\mathrm{v}_{\mathrm{i}}, \mathrm{w}_{\mathrm{j}}\right)\right\}\right.\right. \\
& \left.-\Sigma_{\mathrm{j}}\left\{\mathrm{h}_{\mathrm{j}}\left(\mathrm{w}_{,} \mathrm{v}_{\mathrm{i}}, \mathrm{v}_{-\mathrm{i}}\right) \delta_{\mathrm{v}}{ }^{\prime}\left(\mathrm{v}_{\mathrm{i}}, \mathrm{w}_{\mathrm{j}}\right)\left(\rho_{\mathrm{v}}\left(\mathrm{v}_{\mathrm{i}}\right)\right)^{-1}\right\}\right]-\mathrm{U}_{\mathrm{i}}(0,0)
\end{aligned}
$$


Aggregating over all bidders, yields the total expected proceeds for the seller as TR where:

$\mathrm{TR}=\mathrm{E}_{\mathrm{v}, \mathrm{w}}\left[\Sigma_{\mathrm{i}} \mathrm{q}_{\mathrm{i}}\left(\mathrm{v}_{\mathrm{i}}, \mathrm{v}_{-\mathrm{i}}, \mathrm{w}\right)\left(\mathrm{v}_{\mathrm{i}}-\left(\rho_{\mathrm{v}}\left(\mathrm{v}_{\mathrm{i}}\right)\right)^{-1}\right)+\Sigma_{\mathrm{j}} \mathrm{h}_{\mathrm{j}}\left(\mathrm{w}_{\mathrm{j}}, \mathrm{w}_{-\mathrm{j}}, \mathrm{v}\right)\left(\mathrm{w}_{\mathrm{j}}-\left(\rho_{\mathrm{w}}\left(\mathrm{w}_{\mathrm{j}}\right)\right)^{-1}\right)+\right.$

$\Sigma_{\mathrm{j}} \Sigma_{\mathrm{i}}\left\{\mathrm{h}_{\mathrm{j}}\left(\mathrm{w}, \mathrm{v}_{\mathrm{i}}, \mathrm{v}_{-\mathrm{i}}\right) \mathrm{q}_{\mathrm{i}}\left(\mathrm{v}_{\mathrm{i}}, \mathrm{v}_{-\mathrm{i}}, \mathrm{w}\right)\left(\delta_{\mathrm{v}}\left(\mathrm{v}_{\mathrm{i}}, \mathrm{w}_{\mathrm{j}}\right)+\delta_{\mathrm{w}}\left(\mathrm{w}_{\mathrm{j}}, \mathrm{v}_{\mathrm{i}}\right)-\delta_{\mathrm{v}}\left(\mathrm{v}_{\mathrm{i}}, \mathrm{w}_{\mathrm{j}}\right)\left(\rho_{\mathrm{v}}\left(\mathrm{v}_{\mathrm{j}}\right)\right)^{-1}-\right.\right.$

$\left.\left.\left.\delta_{\mathrm{w}}{ }^{\prime}\left(\mathrm{w}_{\mathrm{j}}, \mathrm{v}_{\mathrm{i}}\right)\left(\rho_{\mathrm{w}}\left(\mathrm{w}_{\mathrm{i}}\right)\right)^{-1}\right)\right\}\right]-\Sigma_{\mathrm{i}} \mathrm{U}_{\mathrm{i}}(0,0)-\Sigma_{\mathrm{j}} \mathrm{U}_{\mathrm{j}}(0,0)$

It will be helpful to define the virtual valuations

$\mathrm{J}_{\mathrm{v}}(\mathrm{v})=\mathrm{v}-\left(\rho_{\mathrm{v}}(\mathrm{v})\right)^{-1}$

$J_{w}(w)=w-\left(\rho_{w}(w)\right)^{-1}$

And the corresponding virtual externalities

$\mathrm{K}_{\mathrm{v}}\left(\mathrm{v}_{\mathrm{i}}, \mathrm{w}_{\mathrm{j}}\right)=\delta_{\mathrm{v}}\left(\mathrm{v}_{\mathrm{i}}, \mathrm{w}_{\mathrm{j}}\right)-\delta_{\mathrm{v}}\left(\mathrm{v}_{\mathrm{i}}, \mathrm{w}_{\mathrm{j}}\right)\left(\rho_{\mathrm{v}}\left(\mathrm{v}_{\mathrm{i}}\right)\right)^{-1}$

$\left.\mathrm{K}_{\mathrm{w}}\left(\mathrm{w}_{\mathrm{j}}, \mathrm{v}_{\mathrm{i}}\right)=\delta_{\mathrm{w}}\left(\mathrm{w}_{\mathrm{j}}, \mathrm{v}_{\mathrm{i}}\right)-\delta_{\mathrm{w}}{ }^{\prime}\left(\mathrm{w}_{\mathrm{j}}, \mathrm{v}_{\mathrm{i}}\right)\left(\rho_{\mathrm{w}}\left(\mathrm{w}_{\mathrm{j}}\right)\right)^{-1}\right\}$

And to construct

$\mathrm{H}_{\mathrm{v}}(\mathrm{v}, \mathrm{w})=\mathrm{J}_{\mathrm{v}}(\mathrm{v})+\mathrm{K}_{\mathrm{v}}\left(\mathrm{v}_{\mathrm{i}}, \mathrm{w}_{\mathrm{j}}\right)+\mathrm{K}_{\mathrm{w}}\left(\mathrm{w}_{\mathrm{j}}, \mathrm{v}_{\mathrm{i}}\right)$

$\mathrm{H}_{\mathrm{w}}(\mathrm{v}, \mathrm{w})=\mathrm{J}_{\mathrm{w}}(\mathrm{w})+\mathrm{K}_{\mathrm{v}}\left(\mathrm{v}_{\mathrm{i}}, \mathrm{w}_{\mathrm{j}}\right)+\mathrm{K}_{\mathrm{w}}\left(\mathrm{w}_{\mathrm{j}}, \mathrm{v}_{\mathrm{j}}\right)$

We also assume that a regularity condition holds: that $\mathrm{J}_{\mathrm{v}}(\mathrm{v})$ and $\mathrm{H}_{\mathrm{v}}(\mathrm{v}, \mathrm{w})$ are both increasing in $\mathrm{v},{ }^{6}$ and $\mathrm{J}_{\mathrm{w}}(\mathrm{w})$ and $\mathrm{H}_{\mathrm{w}}(\mathrm{w}, \mathrm{v})$ are both increasing in $\mathrm{w}$. Then, dropping the arguments of $\mathrm{q}_{\mathrm{i}}($.$) and \mathrm{h}_{\mathrm{j}}($.$) , allows (10)$ to be rewritten as

\footnotetext{
${ }^{6}$ This assumes that the hazard function does not decline too rapidly with $\mathrm{v}$.
} 
$\mathrm{TR}=\mathrm{E}_{\mathrm{v}, \mathrm{w}}\left[\Sigma_{\mathrm{i}} \mathrm{q}_{\mathrm{i}} \mathrm{J}_{\mathrm{v}}\left(\mathrm{v}_{\mathrm{i}}\right)+\Sigma_{\mathrm{j}} \mathrm{h}_{\mathrm{j}} \mathrm{J}_{\mathrm{w}}\left(\mathrm{w}_{\mathrm{j}}\right)+\Sigma_{\mathrm{j}} \Sigma_{\mathrm{i}}\left\{\mathrm{h}_{\mathrm{j}} \mathrm{q}_{\mathrm{i}}\left(\mathrm{K}_{\mathrm{v}}\left(\mathrm{v}_{\mathrm{i}}, \mathrm{w}_{\mathrm{j}}\right)+\mathrm{K}_{\mathrm{w}}\left(\mathrm{w}_{\mathrm{j}}, \mathrm{v}_{\mathrm{i}}\right)\right)\right\}\right]-\Sigma_{\mathrm{i}} \mathrm{U}_{\mathrm{i}}(0,0)-$ $\Sigma_{\mathrm{j}} \mathrm{U}_{\mathrm{j}}(0,0)$

The equation (13) is the fundamental equation for analysis. To maximize TR the utility of types with zero values must be zero. Thus we will set $\mathrm{U}_{\mathrm{i}}(0,0)=\mathrm{U}_{\mathrm{j}}(0,0)=0$. An optimal mechanism is a non-negative vector of $q_{i}$ and $h_{j}$ which describe the probability of allocation for each possible $\{\mathrm{v}, \mathrm{w}\}$, and where $\Sigma_{\mathrm{i}} \mathrm{q}_{\mathrm{i}} \leq 1$ and $\Sigma_{\mathrm{j}} \mathrm{h}_{\mathrm{j}} \leq 1$, such that TR is maximized. Thus at some particular $\{\mathrm{v}, \mathrm{w}\}$ it might for example be the case that $\mathrm{q}_{1}=\mathrm{h}_{1}=$ 1 , while all other $\mathrm{q}$ and $\mathrm{h}$ values are zero. To determine the optimal mechanism, first note that, due to the regularity conditions, TR is always increased by only ever allocating $\mathrm{V}$ to the highest v-type and only ever allocating $\mathrm{W}$ to the highest $\mathrm{w}$-type. Therefore attention can be confined to only the highest types in the two samples. ${ }^{7}$ Thus denote $\mathrm{v}^{*}$ and $\mathrm{w}^{*}$ as the highest types in the samples, and assume these are uniquely observed. ${ }^{8}$ Then the optimal policy has the properties that

$$
\begin{aligned}
& \mathrm{q}_{\mathrm{i}}\left(\mathrm{v}_{\mathrm{i}}, \mathrm{v}_{-\mathrm{i}}, \mathrm{w}\right)=0 \text { if } \mathrm{v}_{\mathrm{i}}<\mathrm{v}^{*} \\
& \mathrm{~h}_{\mathrm{j}}\left(\mathrm{w}_{\mathrm{j}}, \mathrm{w}_{-\mathrm{j}}, \mathrm{v}\right)=0 \text { if } \mathrm{w}_{\mathrm{j}}<\mathrm{w}^{*} \\
& \mathrm{q}_{\mathrm{i}}^{*}=\mathrm{q}_{\mathrm{i}}\left(\mathrm{v}^{*}, \mathrm{v}_{-\mathrm{i}}, \mathrm{w}\right)=0 \text { or } 1 \\
& \mathrm{~h}_{\mathrm{j}}^{*}=\mathrm{h}_{\mathrm{j}}\left(\mathrm{w}^{*}, \mathrm{w}_{-\mathrm{j}}, \mathrm{v}\right)=0 \text { or } 1
\end{aligned}
$$

There are 4 possibilities:

\footnotetext{
${ }^{7}$ Of course a number of possibilities can occur which would not satisfy the regularity conditions. Some interesting situations may lead to the argument that the top types in each auction are not the optimal selection. Solutions can be studied via equation (13) but with the regularity conditions replaced by special structure.

${ }^{8}$ Continuity of the density function implies uniqueness with probability one.
} 
(a) Both franchises are awarded, $\mathrm{q}_{\mathrm{i}}{ }^{*}=\mathrm{h}_{\mathrm{j}}{ }^{*}=1$.

(b) Only $\mathrm{V}$ is awarded, $\mathrm{q}_{\mathrm{i}}{ }^{*}=1$ and $\mathrm{h}_{\mathrm{j}}{ }^{*}=0$.

(c) Only $\mathrm{W}$ is awarded, $\mathrm{q}_{\mathrm{i}}^{*}=0$ and $\mathrm{h}_{\mathrm{j}}^{*}=1$.

(d) Neither franchise is awarded, $\mathrm{q}_{\mathrm{i}}{ }^{*}=\mathrm{h}_{\mathrm{j}}{ }^{*}=0$.

TR can be evaluated in each case:

$\mathrm{TR}(\mathrm{a})=\mathrm{J}_{\mathrm{v}}\left(\mathrm{v}^{*}\right)+\mathrm{J}_{\mathrm{w}}\left(\mathrm{w}^{*}\right)+\mathrm{K}_{\mathrm{v}}\left(\mathrm{v}_{\mathrm{i}}, \mathrm{w}_{\mathrm{j}}\right)+\mathrm{K}_{\mathrm{w}}\left(\mathrm{w}_{\mathrm{j}}, \mathrm{v}_{\mathrm{i}}\right)$

$\mathrm{TR}(\mathrm{b})=\mathrm{J}_{\mathrm{v}}\left(\mathrm{v}^{*}\right)$

$\mathrm{TR}(\mathrm{c})=\mathrm{J}_{\mathrm{w}}\left(\mathrm{w}^{*}\right)$

$\mathrm{TR}(\mathrm{d})=0$

We can now state the following proposition.

Proposition 1. Provided the regularity conditions hold, the optimal allocation in the joint auction is described in the following way.

Allocate at least $\mathrm{V}$ if $\mathrm{J}_{\mathrm{v}}\left(\mathrm{v}^{*}\right)>0$, i.e. $\mathrm{v}^{*}>\mathrm{V}^{\mathrm{c}}$ where $\mathrm{v}^{\mathrm{c}}$ is defined such that $\mathrm{J}_{\mathrm{v}}\left(\mathrm{v}^{\mathrm{c}}\right)=0$. Allocate at least $\mathrm{W}$ if $\mathrm{J}_{\mathrm{w}}\left(\mathrm{w}^{*}\right)>0$, i.e. $\mathrm{w}^{*}>\mathrm{w}^{\mathrm{c}}$.

Allocate both if $\mathrm{J}_{\mathrm{v}}\left(\mathrm{v}^{*}\right)+\mathrm{J}_{\mathrm{w}}\left(\mathrm{w}^{*}\right)+\mathrm{K}_{\mathrm{v}}\left(\mathrm{v}_{\mathrm{i}}, \mathrm{w}_{\mathrm{j}}\right)+\mathrm{K}_{\mathrm{w}}\left(\mathrm{w}_{\mathrm{j}}, \mathrm{v}_{\mathrm{i}}\right)>\max \left\{0, \mathrm{~J}_{\mathrm{v}}\left(\mathrm{v}^{*}\right), \mathrm{J}_{\mathrm{w}}\left(\mathrm{w}^{*}\right)\right\}$ 
Proof. Directly from equations (14) and (15).

The equation which divides cases where the allocation of both franchises is profitable from those cases where it is not is:

$\operatorname{TR}(\mathrm{a})=\mathrm{J}_{\mathrm{v}}\left(\mathrm{v}^{*}\right)+\mathrm{J}_{\mathrm{w}}\left(\mathrm{w}^{*}\right)+\mathrm{K}_{\mathrm{v}}\left(\mathrm{v}_{\mathrm{i}}, \mathrm{w}_{\mathrm{j}}\right)+\mathrm{K}_{\mathrm{w}}\left(\mathrm{w}_{\mathrm{j}}, \mathrm{v}_{\mathrm{i}}\right)=0$

This is downward sloping, i.e. $\mathrm{dw}^{*} / \mathrm{dv}^{*}<0$ for solution points since $\mathrm{H}_{\mathrm{v}}(),. \mathrm{H}_{\mathrm{w}}($.$) are$ assumed increasing functions. Also note that if $\mathrm{f}($.$) and \mathrm{g}($.$) are the same density$ functions, and, in addition, both bidders have the same (symmetric) externality functions, then if $\left\{\mathrm{v}_{1}, \mathrm{w}_{1}\right\}$ solves (16) so does $\left\{\mathrm{w}_{1}, \mathrm{v}_{1}\right\}$. Then TR(a) is symmetric about a $45^{\circ}$ line. The equation which divides cases where joint allocation is more profitable for the seller from those where the single allocation of $\mathrm{V}$ is better is given by:

$\operatorname{TR}(\mathrm{a})=\mathrm{J}_{\mathrm{v}}\left(\mathrm{v}^{*}\right)+\mathrm{J}_{\mathrm{w}}\left(\mathrm{w}^{*}\right)+\mathrm{K}_{\mathrm{v}}\left(\mathrm{v}_{\mathrm{i}}, \mathrm{w}_{\mathrm{j}}\right)+\mathrm{K}_{\mathrm{w}}\left(\mathrm{w}_{\mathrm{j}}, \mathrm{v}_{\mathrm{i}}\right)=\mathrm{J}_{\mathrm{v}}\left(\mathrm{v}^{*}\right)=\mathrm{TR}(\mathrm{b})$

or $\mathrm{H}_{\mathrm{w}}\left(\mathrm{w}^{*}, \mathrm{v}^{*}\right)=0$

Equation (17) is again downward sloping provided $\mathrm{K}_{\mathrm{v}}\left(\mathrm{v}^{*}, \mathrm{w}^{*}\right)+\mathrm{K}_{\mathrm{w}}\left(\mathrm{w}^{*}, \mathrm{v}^{*}\right)$ is increasing in $\mathrm{v}^{*}$, but is flatter $\left(\mathrm{dw}^{*} / \mathrm{dv}^{*}\right.$ less negative) since $\mathrm{J}($.$) is an increasing function. Also the$ two functions (16) and (17) intersect when $\mathrm{v}^{*}=\mathrm{v}^{\mathrm{c}}$. Figure 1 shows an example of the boundaries of the values of $\mathrm{v}^{*}$ and $\mathrm{w}^{*}$ which lead to allocating one, both or neither franchise. The boundaries in the Figure are drawn for the case where the densities $f(v)$ and $\mathrm{g}(\mathrm{w})$ are both uniform on $[0,1]$, and the externality functions are $\delta_{\mathrm{v}}\left(\mathrm{v}_{\mathrm{i}}, \mathrm{w}_{\mathrm{j}}\right)=\mathrm{bw}_{\mathrm{j}}$ for bidder $\mathrm{i}$ and $\delta_{\mathrm{w}}\left(\mathrm{w}_{\mathrm{j}}, \mathrm{v}_{\mathrm{i}}\right)=\mathrm{bv}_{\mathrm{i}}$ for bidder $\mathrm{j}$. Figure 2 shows how the regions alter as $\mathrm{b}$ decreases. When $b$ declines to zero, there are no externalities and the solution collapses to 
the usual solution in independent auctions: reserve prices of $\mathrm{v}^{\mathrm{c}}, \mathrm{w}^{\mathrm{c}}$, respectively (in this uniform case: $1 / 2,1 / 2)$.

Before proceeding to draw conclusions, it is interesting to briefly consider the case where the externality is negative. This case is drawn in Figure 3 for the uniform distribution and externality functions $\mathrm{bw}_{\mathrm{j}}, \mathrm{bv}_{\mathrm{i}}$. Here, if $\mathrm{v}^{*}<\mathrm{v}^{\mathrm{c}}$, then again $\mathrm{V}$ is not allocated. It is also not allocated if $\mathrm{w}^{*}>\mathrm{v}^{*}>\mathrm{v}^{\mathrm{c}}$ unless $\mathrm{v}^{*}$ is substantially higher than $\mathrm{v}^{\mathrm{c}}$. This reflects the desire of the seller to choose only one franchise $\left(\mathrm{V}\right.$ or $\mathrm{W}$ depending on whether $\mathrm{v}^{*}$ or $\mathrm{w}^{*}$ is the larger) unless they can both be sold to very high types.

The interpretation of Figure 1, and the more general analysis that it illustrates, is of considerable interest, and the following points are of particular note.

1. As in the simple example of section 1, the optimal policy is to allocate $V$ by discriminating on the basis of whether $\mathrm{W}$ is also being allocated. Thus the minimum $\mathrm{v}^{*}$ for $\mathrm{V}$ to be allocated is $\mathrm{v}^{\mathrm{c}}$ if $\mathrm{w}^{*}$ is less than some value, then declines as $\mathrm{w}^{*}$ increases. The bidder faces a "minimum type" schedule. In the uniform case, only types less than $(1-b) /(2+b)$ will never be allocated a franchise. If $b=0$, this is the familiar result of $1 / 2$. As the positive externality increases, so the qualification for $\mathrm{V}$ to be allocated becomes easier to meet.

2. A bidder is only ruled out for certain if no allocation will be made to that bidder even under the most favourable externality conditions. In the uniform case, since only types less than $(1-b) /(2+b)$ can never be allocated a franchise, only these types have zero expected utility. If $b=1$, so that each bidder is equally affected by her own type and the type of the $\mathrm{W}$ franchisee, then all bidder types (greater than zero) in the uniform case have positive expected utility. 
3. The possibility of non-allocation is reduced by the positive externality. The allocation mechanism is clearly different in the joint auction than in independent simultaneous auctions. The allocation rule for $\mathrm{V}$ is essentially contingent on the allocation of $\mathrm{W}$, and vice versa. The message is thus that complementary products must be allocated within a joint mechanism, if an optimal allocation is to result.

4. The boundary functions are independent of $\mathrm{n}$ and $\mathrm{m}$, the numbers of bidders for each franchise. Thus whether or not a franchise is allocated depends on $\mathrm{v}^{*}$ and $\mathrm{w}^{*}$, but not directly on $\mathrm{n}$ and $\mathrm{m}$.

5. Figure 1 is reminiscent of the monopoly sale of bundles of products (see Adams and Yellen (1976) and Lewbel (1985)). Thus just as the optimal mechanism in a single auction can be interpreted in terms of the monopolist's positioning along a demand curve (Bulow and Roberts, (1989)), so the optimal mechanism here can be interpreted in terms of the package policy of a monopolist.

6. General analysis of the optimal design has yielded only limited results, but more specific examples can be solved reasonably easily, subject to satisfying the regularity conditions. Explorations with simple externality functions suggest that there are many instances that satisfy these conditions. The symmetric uniform case is just one such example.

\section{An Indirect Mechanism}

The implementation of an optimal mechanism is rarely envisaged as an application of the direct truth-telling mechanism. Instead, a simple indirect mechanism which has 
equivalent allocative properties, and hence is similarly optimal (Myerson,1981) is suggested. A simple indirect mechanism in the present model is stated in Proposition 2.

Proposition 2. If the regularity assumptions hold and if

$$
\mathrm{v}_{\mathrm{i}}-\left\{\mathrm{E}_{\mathrm{v}_{-} \mathrm{i}, \mathrm{w}} \quad \begin{array}{l}
\left.\int_{0}^{\mathrm{i}} \mathrm{Q}_{\mathrm{i}}\left(\mathrm{z}, \mathrm{v}_{-\mathrm{i}}, \mathrm{w}\right) \mathrm{dz}\right\} /\left\{\mathrm{E}_{\mathrm{V}-\mathrm{i}, \mathrm{w}} \mathrm{q}_{\mathrm{i}}\left(\mathrm{v}_{\mathrm{i}}, \mathrm{v}_{-\mathrm{i}}, \mathrm{w}\right)\right\} \\
0
\end{array}\right.
$$

is an increasing function of $\mathrm{v}_{\mathrm{i}}$ (effectively if $\delta_{\mathrm{v}}{ }^{\prime}\left(\mathrm{v}_{\mathrm{i}}, \mathrm{w}_{\mathrm{j}}\right)$ is not too large), then the following describes a feasible indirect mechanism for the implementation of the optimal mechanism.

Each bidder for $\mathrm{V}$ makes a sealed bid $\phi$. Each bidder for $\mathrm{W}$ makes a sealed bid $\gamma$. The highest bids received are denoted $\phi^{*}, \gamma^{*}$ respectively. The seller infers $\mathrm{v}^{*}$ and $\mathrm{w}^{*}$ from $\phi^{*}$ and $\gamma^{*}$, and her knowledge of equilibrium bidding strategies $\phi(\mathrm{v})$ and $\gamma(\mathrm{w})$. Whether either or both $\mathrm{V}$ and $\mathrm{W}$ are allocated is determined by the conditions (15), or equivalently by their analogues for $\phi$ and $\gamma$. If only one is awarded, say $\mathrm{V}$, then $\phi^{*}$ is paid. If both are allocated, then $\phi^{*}+\delta_{\mathrm{V}}\left(\phi^{-1}\left(\phi^{*}\right), \gamma^{-1}\left(\gamma^{*}\right)\right)$ is paid by the winner of $\mathrm{V}$ and $\gamma^{*}+\delta_{\mathrm{w}}\left(\gamma^{-1}\left(\gamma^{*}\right), \phi^{-1}\left(\phi^{*}\right)\right)$ is paid by the winner of $\mathrm{W}$.

Proof. The proof consists of showing that equilibrium bidding strategies $\phi(v)$ and $\gamma(w)$ exist and are strictly monotonically increasing. Then $\mathrm{v}$ and $\mathrm{w}$ can be inferred by the seller from the bids, and the allocation executed. The expected payment by bidder i of type $\mathrm{v}_{\mathrm{i}}$ for franchise $\mathrm{V}$ has been denoted $\mathrm{R}_{\mathrm{i}}\left(\mathrm{v}_{\mathrm{i}}\right)$. Now suppose we decompose this into a component payable if $\mathrm{W}$ is not allocated and an additional component payable if $\mathrm{W}$ is allocated. Thus

$$
\mathrm{R}_{\mathrm{i}}\left(\mathrm{v}_{\mathrm{i}}\right)=\phi \mathrm{E}_{\mathrm{v}-\mathrm{i}, \mathrm{w}} \mathrm{q}_{\mathrm{i}}+\mathrm{E}_{\mathrm{v}-\mathrm{i}, \mathrm{w}} \Sigma_{\mathrm{j}} \mathrm{q}_{\mathrm{i}} \mathrm{h}_{\mathrm{j}} \delta_{\mathrm{v}}\left(\phi^{-1}\left(\phi^{*}\right), \mathrm{w}_{\mathrm{j}}\right)
$$


Equate (18) with (6), simplify and rearrange to obtain

$\phi=\mathrm{v}_{\mathrm{i}}-\left\{\mathrm{E}_{\mathrm{v}_{-} \mathrm{i}, \mathrm{w}} \quad \int_{0}^{\mathrm{v}_{\mathrm{i}}^{\mathrm{i}}} \mathrm{Q}_{\mathrm{i}}\left(\mathrm{z}, \mathrm{v}_{-\mathrm{i}}, \mathrm{w}\right) \mathrm{dz}\right\} / \mathrm{E}_{\mathrm{v}_{-} \mathrm{i}, \mathrm{w}} \mathrm{q}_{\mathrm{i}}\left(\mathrm{v}_{\mathrm{i}}, \mathrm{v}_{-\mathrm{i}}, \mathrm{w}\right)$

Equation (19) gives the bidding rule $\phi\left(\mathrm{v}_{\mathrm{i}}\right)$ for those bidding for $\mathrm{V}$. A symmetric expression holds for those bidding for $\mathrm{W}$ and defines $\gamma(\mathrm{w})$. Since, by assumption, (19) is increasing in $\mathrm{v}_{\mathrm{i}}, \phi^{\prime}\left(\mathrm{v}_{\mathrm{i}}\right)>0$, so that observing $\phi$ permits the government to infer $\mathrm{v}_{\mathrm{i}}$. This completes the proof.

We consider the following example. Assume again that both densities are uniform on the unit interval and that the externality functions are $\mathrm{bw}_{\mathrm{j}}, \mathrm{bv}_{\mathrm{i}}$, and that there are $\mathrm{n}$ bidders for $\mathrm{V}$ and $\mathrm{m}$ for $\mathrm{W}$. The direct mechanism was shown in Figure 1. Consider a bidder for $\mathrm{V}$ with type $\mathrm{v}_{\mathrm{i}}$. Then

$$
\begin{array}{ll}
\mathrm{E}_{\mathrm{v}-\mathrm{i}, \mathrm{w}}\left(\mathrm{q}_{\mathrm{i}}\right)=0 & \text { if } \mathrm{v}_{\mathrm{i}}<(1-\mathrm{b}) /(2+\mathrm{b}) \\
\mathrm{E}_{\mathrm{v}-\mathrm{i}, \mathrm{w}}\left(\mathrm{q}_{\mathrm{i}}\right)=\mathrm{v}_{\mathrm{i}}{ }^{\mathrm{n}-1}\left(1-\mathrm{w}_{\mathrm{s}}{ }^{\mathrm{m}}\right) & \text { if }(1-\mathrm{b}) /(2+\mathrm{b})<\mathrm{v}_{\mathrm{i}}<(1-\mathrm{b} / 2) /(2+\mathrm{b}) \\
\mathrm{E}_{\mathrm{v}-\mathrm{i}, \mathrm{w}}\left(\mathrm{q}_{\mathrm{i}}\right)=\mathrm{v}_{\mathrm{i}} \mathrm{n}^{\mathrm{n}-1}\left(1-\mathrm{w}_{\mathrm{t}}{ }^{\mathrm{m}}\right) & \text { if }(1-\mathrm{b} / 2) /(2+\mathrm{b})<\mathrm{v}_{\mathrm{i}}<1 / 2 \\
\mathrm{E}_{\mathrm{v}-\mathrm{i}, \mathrm{w}}\left(\mathrm{q}_{\mathrm{i}}\right)=\mathrm{v}_{\mathrm{i}} \mathrm{n}^{\mathrm{n}-1} & \text { if } \mathrm{v}_{\mathrm{i}}>1 / 2 \\
\text { where } \mathrm{w}_{\mathrm{s}}=1 / \mathrm{b}-(2+\mathrm{b}) \mathrm{v}_{\mathrm{i}} / \mathrm{b} & \\
\text { and } \mathrm{w}_{\mathrm{t}}=2 /(2+\mathrm{b})-\mathrm{v}_{\mathrm{i}} . &
\end{array}
$$

In equations (20) the expected value of $\mathrm{q}_{\mathrm{i}}$ is bidder i's assessment of her chance to beat other bidders for $\mathrm{V}$ (note that $\mathrm{v}_{\mathrm{i}}^{\mathrm{n}-1}$ is the chance that $\mathrm{v}_{\mathrm{i}}$ beats all other types in the sample) multiplied by the chance that, if $v_{i}$ is the largest type, $V$ will in fact be allocated. Thus if $\mathrm{v}_{\mathrm{i}}<(1-\mathrm{b}) /(2+\mathrm{b})$, bidder $\mathrm{i}$ will never be allocated $\mathrm{V}$ even if $\mathrm{v}_{\mathrm{i}}$ is $\mathrm{v}^{*}$. If $(1-\mathrm{b}) /(2+\mathrm{b})$ 
$<\mathrm{v}_{\mathrm{i}}<(1-\mathrm{b} / 2) /(2+\mathrm{b})$, then $\mathrm{v}_{\mathrm{i}}$ must be $\mathrm{v}^{*}$ and $\mathrm{w}^{*}$ must be at least $\mathrm{w}_{\mathrm{s}}=1 / \mathrm{b}-(2+\mathrm{b}) \mathrm{v}_{\mathrm{i}} / \mathrm{b}$, in order for i to be successful. Similar arguments hold for the other segments in Figure 1.

The other component of equation (19) is also dependent on the segments of the frontier in Figure 1. Thus define

$$
\begin{array}{ll}
\mathrm{I}_{1}(\mathrm{v})= & \int_{0}^{\mathrm{v}} \mathrm{z}^{\mathrm{n}-1}\left(1-(1 / \mathrm{b}-(2+\mathrm{b}) \mathrm{z} / \mathrm{b})^{\mathrm{m}}\right) \mathrm{dz} \\
\mathrm{I}_{2}(\mathrm{v})= & \begin{array}{l}
\int_{(1-b / 2) /(2+\mathrm{b})}^{\mathrm{v}} \mathrm{z}^{\mathrm{n}-1}(1-(2 /(2+\mathrm{b})-\mathrm{z}) \mathrm{m}) \mathrm{dz} \\
\end{array} \\
\mathrm{I}_{3}(\mathrm{v})=\quad & \int_{1 / 2}^{\mathrm{v}} \mathrm{z}^{\mathrm{n}-1} d \mathrm{z} \\
&
\end{array}
$$

Then, since $\mathrm{Q}_{\mathrm{i}}\left(\mathrm{z}, \mathrm{v}_{-\mathrm{i}}, \mathrm{w}\right)=\mathrm{q}_{\mathrm{i}}\left(\mathrm{z}, \mathrm{v}_{-\mathrm{i}}, \mathrm{w}\right)$ in this example $\left(\right.$ as $_{\mathrm{i}}$ does not occur in the externality function)

$$
\begin{aligned}
& \int_{0}^{\mathrm{v}_{\mathrm{i}}} \mathrm{E}_{\mathrm{v}-\mathrm{i}, \mathrm{w}} \mathrm{q}_{\mathrm{i}}\left(\mathrm{z}, \mathrm{v}_{-\mathrm{i}}, \mathrm{w}\right) \mathrm{dz}=\mathrm{I}_{1}(\mathrm{v}) \quad \text { if } \mathrm{v}_{\mathrm{i}} \leq(1-\mathrm{b} / 2) /(2+\mathrm{b}) \\
& \int_{0}^{\mathrm{v}_{\mathrm{i}}} \mathrm{E}_{\mathrm{v}-\mathrm{i}, \mathrm{w}} \mathrm{q}_{\mathrm{i}}\left(\mathrm{z}, \mathrm{v}_{-\mathrm{i}}, \mathrm{w}\right) \mathrm{dz}=\mathrm{I}_{1}((1-\mathrm{b} / 2) /(2+\mathrm{b}))+\mathrm{I}_{2}(\mathrm{v}) \text { if }(1-\mathrm{b} / 2) /(2+\mathrm{b}) \leq \mathrm{v}_{\mathrm{i}} \leq 1 / 2 \\
& \int_{0}^{\mathrm{v}_{\mathrm{i}}} \mathrm{E}_{\mathrm{v}-\mathrm{i}, \mathrm{w}} \mathrm{q}_{\mathrm{i}}\left(\mathrm{z}, \mathrm{v}_{-\mathrm{i}}, \mathrm{w}\right) \mathrm{dz}=\mathrm{I}_{1}((1-\mathrm{b} / 2) /(2+\mathrm{b}))+\mathrm{I}_{2}(1 / 2)+\mathrm{I}_{3}(\mathrm{v}) \text { if } 1 / 2 \leq \mathrm{v}_{\mathrm{i}}
\end{aligned}
$$

Using the above in (19) completely describes $\phi(v)$. Note that $\phi(v)$ is continuous apart from at $\mathrm{v}=1 / 2$, when it has a discontinuity due to the jump in the probability of success (from $v_{i}{ }^{n-1}\left(1-w_{t}{ }^{m}\right)$ to $v_{i}{ }^{n-1}$ as the schedule no longer requires a condition on $w^{*}$ for $V$ to 
be allocated). The bidding function (19) can be easily evaluated using numerical procedures. Some examples are presented in Table 1.

Table 1 Sealed Bids in the Optimal Indirect Mechanism; $b=0.5$

\begin{tabular}{llllll} 
Case & $\mathrm{n}=\mathrm{m}=1$ & $\mathrm{n}=\mathrm{m}=2$ & $\mathrm{n}=\mathrm{m}=4$ & \multicolumn{2}{c}{$\mathrm{n}=4, \mathrm{~m}=2$} \\
$\mathrm{v}$ & $\phi(\mathrm{v})$ & $\phi(\mathrm{v})$ & $\phi(\mathrm{v})$ & $\phi(\mathrm{v})$ & $\gamma(\mathrm{v})$ \\
\hline .2 & .2 & .2 & .2 & .2 & .2 \\
.25 & .225 & .225 & .227 & .229 & .224 \\
.3 & .250 & .251 & .255 & .261 & .243 \\
.35 & .257 & .265 & .282 & .288 & .256 \\
.4 & .267 & .284 & .314 & .320 & .273 \\
.45 & .279 & .305 & .348 & .355 & .291 \\
.5 & .293 & .343 & .385 & .401 & .312 \\
& & & & & \\
.6 & .355 & .377 & .456 & .465 & .352 \\
.7 & .355 & .416 & .528 & .534 & .394 \\
.8 & .355 & .458 & .602 & .606 & .439 \\
.9 & .355 & .502 & .677 & .679 & .485 \\
1 & .355 & .546 & .751 & .753 & .531 \\
\hline
\end{tabular}

The sealed bids in the Table reflect principles that we would expect. Thus higher types bid more, except when there is only one bidder and only then whether or not to allocate is independent of the externality to be conferred on the other bidder, that is when $v<1 / 2$. A greater number of bidders for $\mathrm{V}$ increase bids for $\mathrm{V}$, but decrease bids for $\mathrm{W}$ since proceeding to allocate $\mathrm{W}$ is less likely to depend on $\mathrm{w}^{*}$. The seller's expected revenue is equal to the bids from the expected highest types, weighted by the probabilities of allocations being made, plus the premia ( $\mathrm{bv}^{*}$ and $\left.\mathrm{bw}^{*}\right)$ if both allocations are made.

\section{Conclusions and Applications}


When it is necessary to sell franchises to different agents then the existence of externalities implies that the optimal mechanism must be contingent in character. Such a mechanism is defined in section 2 and one way of carrying through its implementation is described in section 3. In this section, we first make some additional comments concerning the applicability of our analysis, and then consider the kinds of situation where it seems likely that the contingent auctions analyzed here would be important.

First, we have been concerned with optimal mechanisms in the sense of maximizing seller revenue. These mechanisms are not efficient, and it may be thought that a government would be more concerned with efficiency than revenue-raising. This is a serious issue since it may not be credible for the government to not allocate a franchise when the optimal mechanism calls for this commitment to be honoured. One can imagine political difficulties in such a case. However, many situations relate to the government minimizing payments rather than maximizing revenue. Rail systems generally lose money in a strict commercial sense (British Rail receives subsidies in excess of £1b), and then government will find it politically more acceptable to decline to allocate a franchise, on the grounds that it would cost too much, rather than earn too little. Also, although we have taken a no-allocation outcome as a zero type, this does not imply that no service will be run, only that the level of service would be minimal. ${ }^{9}$ In the case of North Sea Oil, the government has the possibilities of keeping the tract unexplored or undeveloped for many years, until changed competition structure, changed oil prices or changed technology make a better sale possible. In this sense, the political difficulties of leaving tracts unallocated seem relatively minor.

\footnotetext{
${ }^{9}$ Relative to the level of service (in terms of efficiency) that could be provided by a higher type bidder.
} 
We have considered a situation where the seller has to allocate two franchises. ${ }^{10}$ Sometimes, a government will separate the seller into two allocating agents. For example, if bus and rail transport are complementary services and are franchised by two distinct neighbouring district authorities, the government (or more generally the state sector) is committing itself to running independent selling mechanisms. Our analysis has shown the potential loss from such separation, and has pointed to a need for the two allocating agents to come together to allocate contracts in a joint negotiation or bidding process. Within a North Sea context, different governments (eg the UK and Norwegian governments) may similarly benefit from joint selling mechanisms.

Obviously the "optimal mechanism" that we have identified is unlikely to be exactly applicable because of the information necessary for calculation. However consideration should be given to encompassing some of the features that have arisen from our analysis. Thus the fee for running a franchise should be enhanced if high bids are received for other franchises. Also the minimum acceptable bid should be lower if other franchises are allocated. If such refinements are not incorporated, then some way towards the optimum may be achieved by a strictly sequential allocation of franchises. However, this may take a long time and thereby cause other problems of uncertainty, and this question of simultaneous versus sequential auctions has been explored in the Spectrum auctions literature (see Plott (1997)).

Another feature of franchise allocations is that the franchise operator may have to bid quality guarantees as well as a price (see for example Branco (1997)). This is due to the possibility of externalities to the seller from quality characteristics of operating the

\footnotetext{
${ }^{10}$ Extensions of the analysis to more than two franchises should be straight-forward but complicated. Results would be made easier by assumptions of symmetry in the way that the externalities operated. In particular one can envisage situations where the externality effect results from an average of the types operating the other franchises.
} 
franchise. Provided the seller's preferences over income and quality are common knowledge, then the bids will be efficient (seller utility-maximizing for given total expenditure). Then the mechanisms here can be reinterpreted as quality-adjusted bids. ${ }^{11}$ In the event that the seller's preferences are uncertain from the bidders' perspectives, then an element of a lottery is introduced and the outcomes will reflect this (see Cripps and Ireland, 1994).

${ }^{11}$. An exception is where the seller finds it to its advantage to announce a rule that gives a different tradeoff between price and quality than its genuine preferences. 


\section{References}

W. J. Adams and J.L. Yellen, (1976) "Commodity bundling and the burden of monopoly", Quarterly Journal of Economics, 90, 475-498.

Jeremy Bulow and John Roberts, (1989) "The simple economics of optimal auctions", Journal of Political Economy, 97, 1060-1090.

F. Branco (1997) "The design of multidimensional auctions" Rand Journal of Economics, 28, 63-81.

Peter Cramton, (1997) “The FCC Spectrum Auctions: an Early Assessment”, Journal of Economics and Management Strategy, 6.3, 431-495.

Martin Cripps and Norman Ireland (1994), "The design of auctions and tenders with quality thresholds: the symmetric case", Economic Journal, 104, 316-26.

Simon Domberger, S A Meadowcroft and D J Thompson (1986), "Competitive tendering and efficiency: the case of refuse collection", Fiscal Studies, 7, 69-87.

Federal Communications Commission (2000), "Comment sought on modifying the simultaneous multiple round auction design to allow combinatorial (package) bidding" Report no. AUC-00-31-G, Washington, D.C.

Robert G.Hansen, (1985) "Auctions with contingent payments", American Economic Review, 75, 862-5.

K. Hendricks. and Porter, R. H. (1992) "Joint bidding in Federal OCS Auctions", American Economic Review, 82 , 506-511.

Philippe Jehiel, Benny Moldovanu and Ennio Stacchetti (1999) Multidimensional mechanism design for auctions with externalities, Journal of Economic Theory, 85, 25893.

Paul Klemperer (1999) "Auction theory; a guide to the literature", Journal of Economic Surveys, 13, 227-86.

A. Lewbel, (1985) "Bundling of substitutes and complements", International Journal of Industrial Organization, 3, 101-7.

Eric Maskin and John Riley, (1989), "Optimal multi-unit auctions", Frank Hahn (ed) The Economics of Missing Markets, Information, and Games, Clarendon Press: Oxford.

Charles Plott, (1997), "Laboratory Experimental Testbeds:Application to the PCS Auction", Journal of Economics and Management Strategy, 6.3, 605-638.

R. Preston McAfee and John McMillan, (1987) "Auctions and Bidding", Journal of Economic Literature, 25, 699-738.

R. Preston McAfee and John McMillan, (1986) "Bidding for contracts: a principal-agent analysis" Rand Journal of Economics, 17, 326-338. 
Paul Milgrom (1989), "Auctions and bidding: a primer", Journal of Economic Perspectives, 3,3-22.

Roger Myerson (1981), "Optimal auction design", Mathematics of Operations Research, $6,58-73$.

John G. Riley and Willian F. Samuelson, (1981) "Optimal Auctions", American Economic Review, 71, 381-92.

William Vickrey (1961), "Counterspeculation, auctions and competitive sealed tenders", Journal of Finance, 16, 8-37. 
Figure 1: Positive Externalities

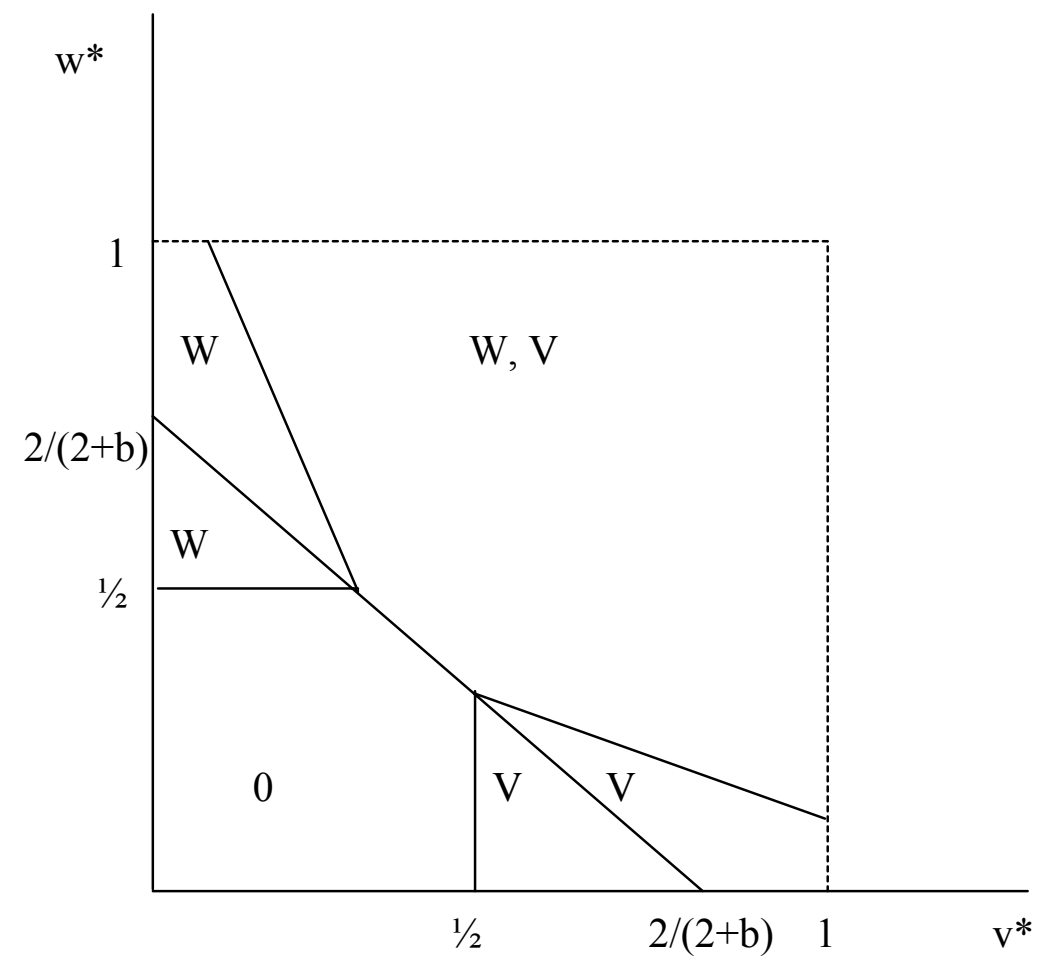


Figure 2: Smaller Positive Externalities

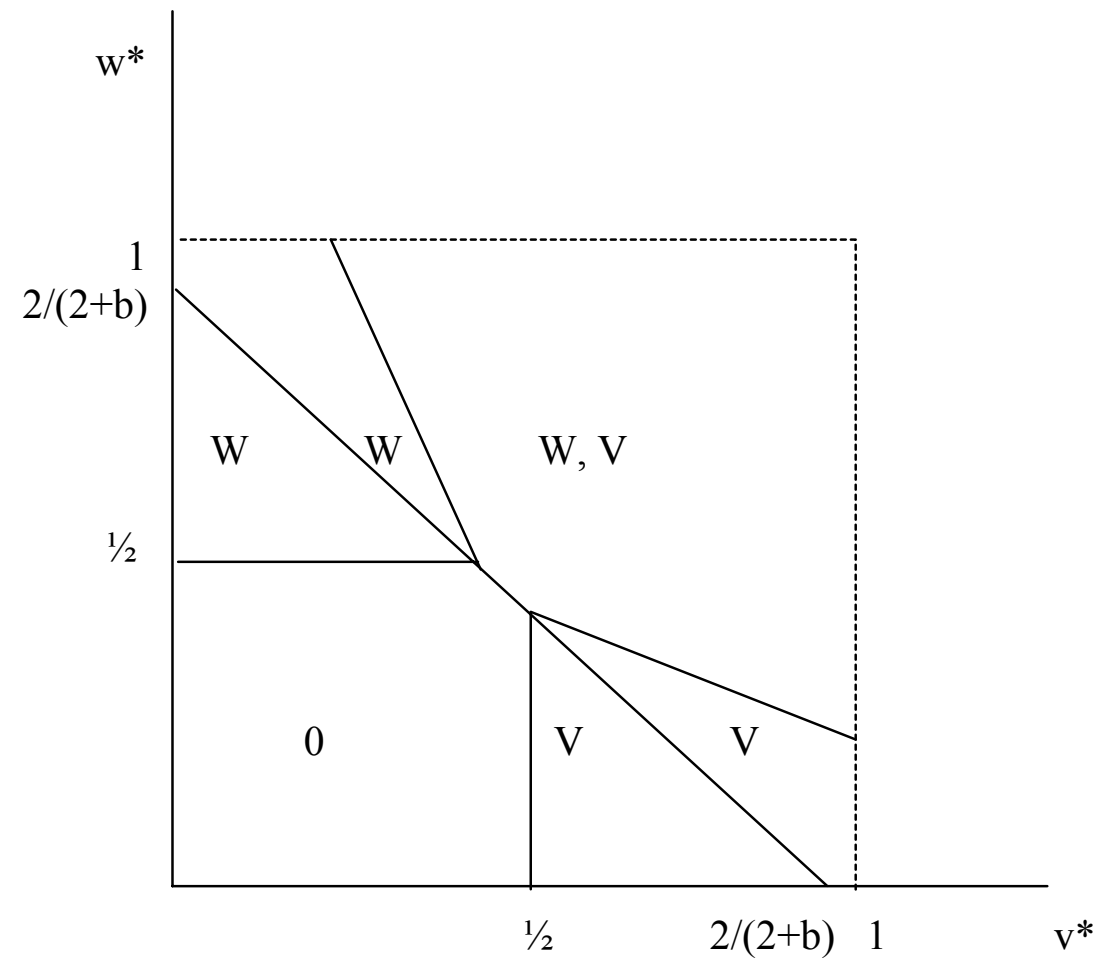


Figure 3: Negative Externalities $(b<0)$

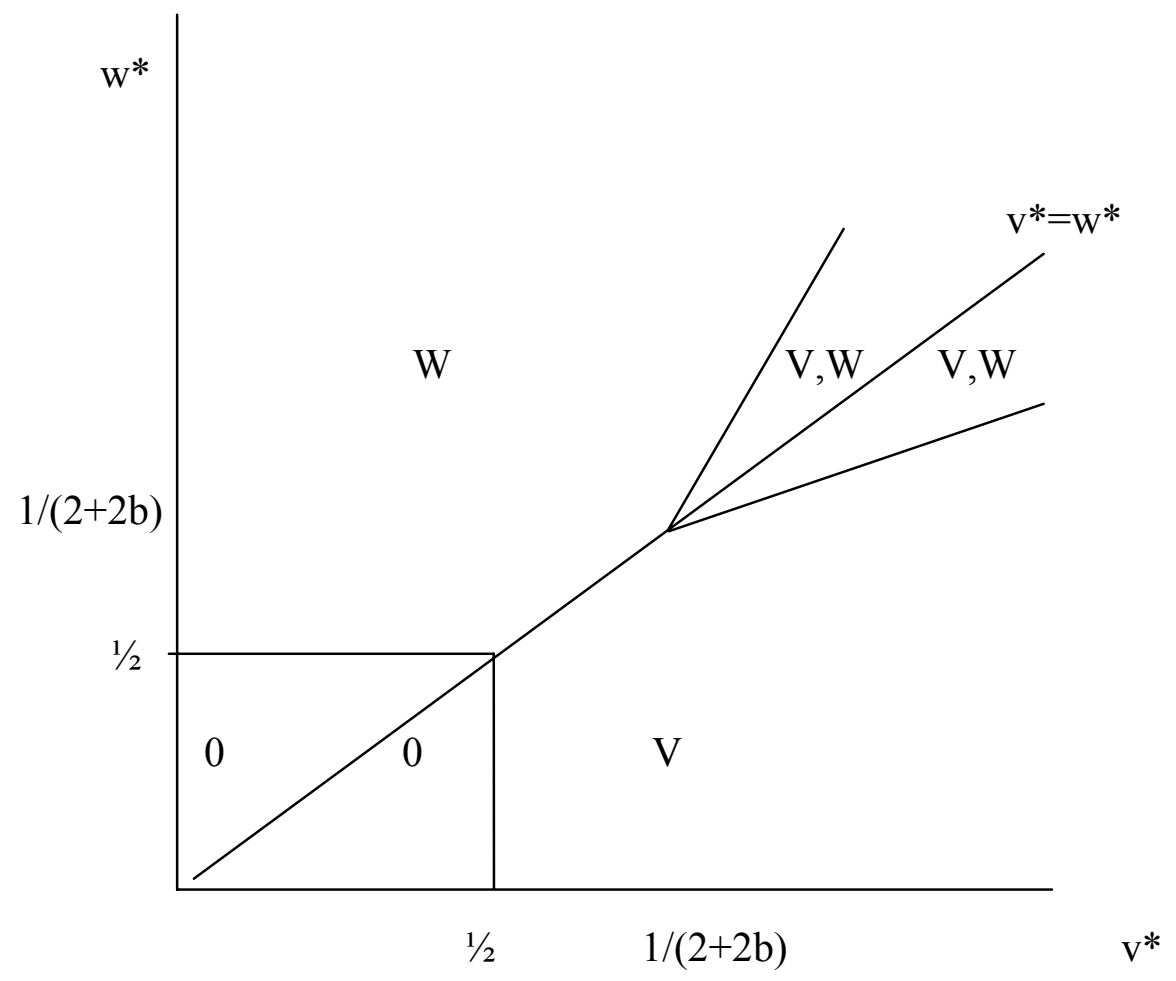

